\title{
Literature as Document
}

Generic Boundaries in 1930s Western Literature

\author{
Edited By \\ Carmen Van den Bergh \\ Sarah Bonciarelli \\ Anne Reverseau
}

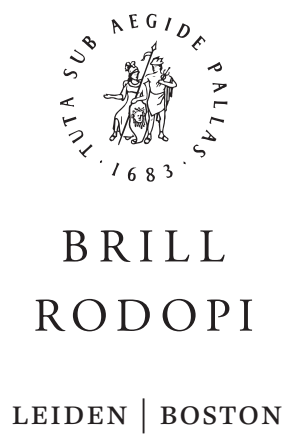

For use by the Author only | ( 2019 Koninklijke Brill NV 


\section{Contents}

Acknowledgements VII

Notes on Contributors VIII

Introduction: Positions and Roles of Literary "Documents":

Textual Games and the Creation of Hybrids 1

Sarah Bonciarelli, Anne Reverseau and Carmen Van den Bergh

\section{PART 1}

Sketching the Document

1 The Difference between "Document" and "Monument" 15

Remo Ceserani

2 A Re-Evaluation of Documentary Tendencies in Neue Sachlichkeit 28 Gunther Martens and Thijs Festjens

\section{PART 2}

Revisiting the Cornerstones

3 Characters as Social Document in Modernist Collective Novels: the Case of Manhattan Transfer 53

Antonio Bibbò

4 Documenting Berlin in the Twenties: War Neurosis and Inflation in Alfred Döblin's Berlin Alexanderplatz $\quad 78$

Stijn De Cauwer and Sven Fabré

5 Building up a "Glasshouse" in Nadja: Documenting the Surrealist Way of Life 103

Nadja Cohen 


\section{PART 3}

Experimental Writings

6 The "Essence of Things" and Their Decomposition: the Use of Montage in Dino Terra's Metamorfosi 121

Achille Castaldo

7 Tardy Presents: Embodied Agency in the "Documental" Poetry of Benjamin Péret and Antonio Porchia 133

Piet Devos and Gys-Walt Van Egdom

\section{PART 4}

Generic Transfers

8 "Madrid está cerca": Spanish Civil War Radio Poetry $\quad 151$ Robin Vogelzang

9 "Documentary" Aspects in Umberto Barbaro's Literary and Cinematographic Practice 165

Fabio Andreazza

10 Plot Placement and Literary Plot: How Economic Context Becomes Part of Literature $\quad 182$

Toni Marino 


\title{
Documenting Berlin in the Twenties: War Neurosis and Inflation in Alfred Döblin's Berlin Alexanderplatz
}

\author{
Stijn De Cauwer and Sven Fabré
}

In 1930, Walter Benjamin pointed out in a review of Alfred Döblin's Berlin Alexanderplatz that the main stylistic principle at work in this novel is montage. The montage passages that fill the novel do not leave the narrative of the novel unaltered. Benjamin remarks: "Die Montage sprengt den Roman, sprengt ihn im Aufbau wie auch stilistisch, und eröffnet neue, sehr epische Möglichkeiten." (110) In words that strongly recall his essay "Der Erzähler", Benjamin claims that montage brings back elements of the epic which otherwise were lost in the modern novel. For this claim, he finds support in Döblin's text "Der Bau des epischen Werks." Benjamin writes that authentic montage is based on the document. As in the work of the Dadaists, reality has to be turned into an ally to give the work greater authenticity. In the review he lists petty-bourgeois printed matter, scandal-mongering, stories of accidents, the sensational incidents of 1928, folk songs, advertisements, biblical verses, statistics, lyrics from songs and the usage of Berlin dialect as examples of documental elements inserted by Döblin into the novel.

It is well-known that Döblin originally just wanted to call his novel Berlin Alexanderplatz but that the publisher Samuel Fischer claimed a square could not be the subject of a novel, and therefore ordered the addition of the subtitle Die Geschichte vom Franz Biberkopf ("The story of Franz Biberkopf"). The juxtaposition of the two parts of the title opens up the tension already described by Benjamin. The subtitle suggests a linear Bildungsroman narrative, describing the progress of a protagonist, while the main title announces the striking

1 Walter Benjamin, Gesammelte Schriften, Band 3, ed Hella Tiedemann-Bartels, Frankfurt am Main: Suhrkamp, 1991, 232. "The montage explodes the framework of the novel, bursts its limits both stylistically and structurally, and clears the way for new epic possibilities." Walter Benjamin, Selected Writings, Volume 2, eds Michael W. Jennings, Howard Eiland, Gary Smith, Cambridge and London, The Belknap Press of Harvard University Press, 1999, 301.

(C) KONINKLIJKE BRILL NV, LEIDEN, 2019 | DOI:10.1163/9789004384255_006 
feature by which Döblin seems to present the city Berlin as a proper character, letting the city "speak for itself", as it were. Scholars have often remarked that Döblin wanted to let his writing be formed by the sights and sounds of Berlin, as if he wanted to let the experience of the city direct his writing. One of the techniques Döblin used to achieve this effect was collecting newspaper articles and other printed material such as announcements or postcards and literally "pasting" them into the manuscript.

While in "Book One" Franz Biberkopf is released from Tegel prison and thrown into the chaotic swirl of the city, making him want to return to the well-ordered life in prison, it is in "Book Two" that the city is introduced as such. In what is probably the most commented-upon passage of the novel, the hustle and bustle of Rosenthaler Platz is described by means of series of shifting techniques. Beginning with the enigmatic statement "Der Rosenthaler Platz unterhält sich", ${ }^{2}$ several pages follow in which the diverse activities taking place on the square are presented from an impersonal perspective. Some of the snippets of daily life inserted into the complex montage are tram stops, names of streets, the offices of the AE G firm, the narrated life story of a boy called Max Rüst, the announcement of the granting of a hunting license, the depiction of a man who was almost killed in an accident, conversations between downtrodden characters, a weather forecast and the different tram fares. David B. Dollenmayer has pointed out the techniques adopted by Döblin are borrowed from film and theatre, such as the literary equivalent of a "tracking shot." In his "Berliner Program" from 1913, Döblin had already pleaded for a so-called "Kinostil." The depiction of modern urban life was better achieved by techniques borrowed from cinema than the traditional conventions of the novel. Dollenmayer distinguishes three different shifts in stylistic approach in the description of life on Rosenthaler Platz: "1) documentary style and absence of narrator, 2) cinematographic style and narrator as monteur, and 3) dramatic style with narration restricted to stage directions." ${ }^{3}$ Furthermore, he has also pointed out that there is a temporal shift in the markers indicating time in the third part with the dialogues, first beginning with the daytime, shifting to later afternoon and ending with the

2 Alfred Döblin, Berlin Alexanderplatz, München, Deutcher Taschenbuch Verlag, 2007, 51. "The Rosenthaler Platz is busily active." Alfred Döblin, Berlin Alexanderplatz, London and New York, Continuum, 2004, 32. This example shows the difficulty of translating Berlin Alexanderplatz into English. The different connotations of the German sich unterhalten are lost in the English translation.

3 David B. Dollenmayer, “An Urban Montage and Its Significance in Döblin's Berlin Alexanderplatz", The German Quarterly, Vol. 53/3 (May, 1980), 325. 
evening, thus giving the reader the feeling of having spent a large part of the day on Rosenthaler Platz. ${ }^{4}(321)$

What should be concluded from this is that the "montage" in Berlin Alexanderplatz is a widely diverse and plural phenomenon. The technique of montage cannot be sufficiently defined by ascribing one single function or operative principle to it. Even in one passage, different forms of montage techniques can be found, which have different effects in each singular instance, bringing into play different "real life documents", allusions or fragments, opening up associations, tensions, ambiguities or unexpected affinities, shifting the perspective or adding layers of meaning to the narration.

We have already seen that Walter Benjamin claimed that the montage adds epic elements and authenticity to the novel, "blasting open" its narrative framework. Though Benjamin does not have the space required in his short review to elaborate on the exact nature of the relation between montage and narration, he suggests that the montage elements break open the general Bildungsroman narrative, rendering it more complex and ambiguous. It has often been observed that the ending of the novel - which allegedly shows a reborn, "cured" Franz Biberkopf facing his new future - is highly ambiguous because of the constant insertion of allusions to war, suggesting the gradual rise of the National Socialists. The military references (marching drum rhythms, soldiers songs and slogans, combat language) inserted into the final pages suggest that a naïve belief in a bourgeois Bildungsroman structure is no longer possible in Döblin's time and possibly dangerously congruent with a decline into fascism.

Scholars such as Wolfgang Schäffner and Eva Horn have highlighted the epistemological consequences of Döblin's usage of montage. ${ }^{5}$ In her article "Literary Research: Narration and the Epistemology of the Human Sciences in Alfred Döblin", Eva Horn situates the work of Döblin in a tradition of novels that aim less for "representational mimesis" of the world than for conducting literary experiments. Authors practising the latter method place the characters in a given constrained situation to observe the consequences. Writers such as Zola argued that both the novel and the sciences share an epistemological impulse. Döblin wanted to describe what he called the "Elementarsituationen

4 Ibid., 321.

5 Wolfgang Schäffner, Die Ordnung des Wahns, Zur Poetologie psychiatrischen Wissen bei Alfred Döblin, München, Wilhemn Fink Verlag, 1995. Eva Horn, "Literary Research: Narration and the Epistemology of the Human Sciences in Alfred Döblin”, MLN, Vol.18/3 (April, 2003), 719739 . 
des menschlichen Daseins" or "Elementarhaltungen des Menschen." Eva Horn explains: "Döblin's poetics of reporting (berichten) attempts to fashion a literary anthropology of modernity by exposing his protagonists to the realms of technology, war, the city, crime, sexuality and social organization." ${ }^{77}$ Wolfgang Schäffner has already shown that Döblin drew in his writing extensively from his work as a psychiatrist. Though mindful of the differences, an "epistemological contiguity" might nevertheless be discerned between the process of writing and the practice of psychiatry. Horn makes one additional remark with regard to the work of Schäffner, namely that the self-reflexive, specific nature of fiction creates a significant difference from the sciences: "Fiction does not just repeat the logic of discourses: it can render them transparent and regulate the textual and epistemological conditions of truth production via a 'Poetologie des Wissens' (poetics of knowledge)." ${ }^{8}$ This poetics of knowledge makes it possible for fiction to transcend "academic disciplines and discursive genres", exposing "the conditions under which statements emerge" and transforming the "frontiers of the 'seeable' and the 'sayable."'"

Horn illustrates her statement with the passage where the murder by Franz of his lover Ida is recounted, the crime for which he was sentenced to prison. The beating to death of Ida is first described in dry scientific language, referring to the Newtonian laws of motion. Döblin even inserts two mathematical formulas into the text. This passage continues with an ice-cold medical description of Ida's fractures. After these absurdly impersonal scientific descriptions of a violent murder scene instigated by a fit of jealousy and alcoholism, the description drastically shifts to passages recounting scenes of violent lamentation taken from Greek mythology, featuring Agamemnon or the Furies. These paratactically inserted snippets of scientific and mythological language can only appear as awkward and out of place to the reader, especially in the description of a brutal murder. In the words of Horn: "Greek tragedy and physics are equally incapable of explaining Franz and Ida's collision; it can neither be described in the language of deterministic logic nor in that of mythical fatalism. It is by using a literary montage technique that Döblin not only exposes this incompatibility but also the heterogeneity of these explanatory elements...." ${ }^{\prime 10}$

Alfred Döblin, Aufsätze zur Literatur, ed Walter Muschg, Olten und Freiburg im Breisgau, Walter Verlag, 1963, 106. This could be translated into English as "Basic situations of human existence" and "Basic positions of human beings" (Our translation).

7 Eva Horn, "Literary Research", 723.

$8 \quad$ Ibid., 721-722.

9 Eva Horn, "Literary Research", 722.

$10 \quad$ Ibid., 728. 
In times when scientific and mythological determinist views were increasingly popular and increasingly politically abused, Döblin's montage technique exposes the fact that a single explanatory narrative or overly one-sided causal explanation of human experience in the modern city will not be adequate. Moreover, instead of being offered simple causal narratives or easy answers, the reader witnesses the different explanatory models in the moment of their formation.

Finally, in "Döblin's Epic: Sense, Document, and the Verbal World Picture",11 Devin Fore describes the changes in the way Döblin uses documents between his novel Die beiden Freundinnen und ihr Giftmord from 1923 and Berlin Alexanderplatz. In Die beiden Freundinnen, Döblin had used an actual crime scene as the source for his book, adding a large amount of real-life archival documents about the crime at the end of the novel. During the writing of Die beiden Freundinnen, Döblin aimed for a form of realist reportage, seeking a literary style adequate to the description of real-life events. However, such a view remains stuck in a dualistic theory of correspondence, whereby literature is allegedly completely separated from "reality" or "experience" and whereby literature has to try to achieve as much similitude as possible - an argument which will always be inadequate. Between Die beiden Freundinnen and Berlin Alexanderplatz, Döblin had written a series of theoretical texts, such as the Spinoza-influenced "Das Ich über der Natur" in 1927 and "Der Geist des naturalistischen Zeitalters" in 1924. Moreover, as Fore convincingly shows, Döblin had been increasingly influenced by the theories of Fritz Mauthner.

Fore argues, accordingly, that the entire narrative structure of Berlin Alexanderplatz is simply a means for Döblin to display his new view on a literary practice "that fused production and reception together at the scene of the text's performance and that thereby bound the author, narrator, audience, and character together as 'part of a real, existential present.'"12 Literature is now a form of experience which like all experience is part of the dynamic, constantly changing swirl of everyday life. Döblin preferred to let his writing be guided by the sensory experience of life in Berlin. ${ }^{13}$ According to Fore, Döblin's new

11 Devin Fore, "Döblin's Epic: Sense, Document, and the Verbal World Picture", New German Critique, No.99 (Fall, 2006), 171-207.

12 Devin Fore, "Döblin's Epic", 187.

13 Fore claims that "Biberkopf operates as a sort of textual prosthesis for Döblin: he is not a person but an instrument for Döblin to give form to his own experiences from the time he began writing mid-October 1927 to the spring of 1929." Devin Fore, "Döblin's Epic", 198. He finds Berlin Alexanderplatz more an "experimental biography" of Döblin or a "documentary text" than "The story of Franz Biberkopf." Fore places here all weight on the montage aspect of the novel at the cost of the narrative. However, if these montage elements 
approach reflects what Mauthner called a "verbal picture of the world", "which is oriented not toward ontology (Sein, a word that Mauthner despised) but toward morphology (Werden), toward transformation and mutability...."14 The experience of life in Berlin that Döblin evoked in Berlin Alexanderplatz was a highly dynamic one.

This brief sketch of some of the different readings by scholars of the use of montage in Berlin Alexanderplatz and of the way this montage is put to work to document life in Berlin shows that Döblin's montage cannot be reduced to a single form, principle or function. Rather it is a technical device, consisting of multiple varieties and kinds, which aims to do justice to the full complexity - including epistemological issues and multi-sensorial experience - of life in Berlin during the chaotic and volatile Weimar Republic. In what follows, this essay looks more closely at the way two very striking and important features of life during the Weimar Republic are creatively evoked and documented in Berlin Alexanderplatz, namely, the phenomenon of war neurosis and the experience of extreme inflation.

In 1921, an article by Döblin, written under his pseudonym "Linke Poot", was published in the Frankfurter Allgemeine with the title "Das kranke Volk." The title was taken from the writings of Ernst Simmel, one of the founding figures of the Berlin Psychoanalytic Institute. Simmel was a pioneer in the psychoanalytic study of the phenomenon of Kriegsneurose (war neurosis) and from 1919 he became Döblin's analyst during his training to become a psychoanalyst. ${ }^{15}$ Döblin had studied medicine and psychiatry and worked in traditional psychiatric facilities before serving as an army doctor during the First World War. Already before the war, Döblin felt a dissatisfaction with the methods and diagnostic categories advocated by the psychiatric establishment. The supervisor of his dissertation on Korsakoff's psychosis was nobody else than Alfred

are not inserted into a specific narrative framework, the montage would lose all effect and power.

14 Devin Fore, “Döblin's Epic", 201.

15 Veronika Fuechtner has written a great book clarifying the theories and practices of the Berlin Psychoanalytic Institute, including a chapter on the relationship of Simmel and Döblin: Veronika Fuechtner, Berlin Psychoanalytic, Psychoanalysis and Culture in Weimar Republic Germany and Beyond, Berkeley, Los Angeles, London, University of California Press, 2011. 
Hoche, the psychiatrist who, together with Karl Binding, wrote a controversial manifesto in 1920, arguing for the euthanasia of "inferior life forms." Though Hoche ultimately disagreed with the brutality of the Nazi policies, his manifesto nevertheless served to set the tone for an aggressive treatment, not to mention mass murder, of people with certain disabilities. This conflict between the harsh methods used by psychiatrists and increased psychological suffering became even more pronounced during the First World War. The war served as a catalyst in the development of new psychiatric theories and methods, and many doctors serving at the front were appalled by the heartless and violent treatment of soldiers who suffered from symptoms of shell shock, which the war, with its unprecedented scale and usage of modern technologies designed for mass destruction, engendered in immense quantities. Treatments such as the Kaufmann method, combining high-voltage electroshock "therapy" with verbal intimidation, bordered on torture. An allusion to this treatment is made in the passage in Berlin Alexanderplatz where Franz's case is being discussed by the doctors of the Buch hospital. ${ }^{16}$

As Döblin wrote in the article from 1921, it could no longer be ignored that the legions of soldiers who returned traumatized from the front, as well as the civilian population that lived through the hardships of war and defeat, were still suffering from the war in a way that strongly impacted society. In his medical practice in the centre of Berlin, Döblin witnessed the devastating consequences of the war on a daily basis. Though Döblin and the other members of the Berlin Psychoanalytic Institute would continually regard Freud with the highest esteem, they differed from Freud on one important issue. The Berlin psychoanalysts believed that psychoanalysis was needed to cure society from the traumas of the war. In order to do so, the psychoanalytic method had to be put to practice as widely as possible, available for an affordable price - or even better, for free, and, most importantly - it should reach the parts of the population most affected by the war: the working class. The members of the Berlin Psychoanalytic Institute had an unambiguous socialist agenda and several of them, Döblin included, were also member of a union of socialist physicians (namely, the "Verein Sozialistischer Ärzte"). Simmel and others established a polyclinic in Berlin in 1920, where low-cost treatment was provided and practical courses on psychoanalytic methods were taught.

The devastating impact of the war on the psychological life and social relations of the citizens of the Weimar Republic certainly was of central importance

16 Alfred Döblin, Berlin Alexanderplatz, 426. This passage is filled with references to actual discussions going on in psychiatry as Döblin knew from his own experience.

For use by the Author only | (c 2019 Koninklijke Brill NV 
in artistic and political assessments of life in Berlin during the Twenties. Many other Berlin artists - most famously the Expressionist and Dadaist artists - displayed the mechanized, fragmented and dysfunctional "war cripple" in their works. Though they were a familiar sight in the Berlin streets, manifestly magnifying their predicament was considered to be a political statement against the war and the political class that had instigated it. ${ }^{17}$ Not surprisingly, the symptoms of war neurosis also prevail in Berlin Alexanderplatz.

Of all the members of the Berlin Psychiatric Institute, it was Ernst Simmel who made the greatest effort to develop a clinical picture of war neurosis. From his clinical experiences with traumatized soldiers, Simmel tried to describe the effects of exposure to the terror of war and the experience of undergoing military drill on the regular psychological structure of an individual. The front experience drastically alters the functioning of the psyche. These changes continue in peacetime, strongly reducing the veteran's ability to function as a socially apt citizen and, given the quantity of people afflicted, threatening society in general. War neurosis is described by Simmel as a personality split ("Persönlichkeitsspaltung"). ${ }^{18}$ The experiences associated with traumatic events are strongly repressed but this repressed material will nevertheless seek an outlet via a series of psycho-somatic symptoms. It is important to stress that for Simmel, the symptoms of Kriegsneurose are one mechanism of the psyche for protecting itself ("Selbstsicherungsprozeß der Psyche"). ${ }^{19}$ They are an attempt to reconstruct the fractured personality and an attempt at self-healing, even protecting the soldier from completely disintegrating into psychosis. ${ }^{20}$

Whereas normally one's most primal drives and impulses, coming from our $I d$, are kept under control by our Über-Ich (Simmel adopts the Freudian topology of the psyche), which has internalized society's moral norms, these "normal" self-restrictions are broken during a military drill. The soldier is supposed to obey his superiors at all costs and, especially in a war situation, the soldier is drilled and forced to commit acts (of murder, destruction, violence etc.) which in civilian life would be regarded as highly immoral. The soldier's

17 In 1937, the painting Kriegskrüppel by Otto Dix, showing a group of war cripples with contorted features reflecting the inhuman mechanization they were exposed to on the front, or Die wildgewordene Spießer Heartfield (Elektromechanische Tatlin-Plastik) by John Heartfield and Georg Grosz, an installation resembling a dysfunctional war veteran, featured prominently in the Nazi propaganda exposition on Entartete Kunst, under the heading of "Wehrsabotage", before they were destroyed.

18 Ernst Simmel, Psychoanalyse und ihre Anwendungen. Ausgewählte Schriften, eds Ludger M. Hermanns, Ulrich Schultz-Venrath, Frankfurt am Main, Fischer Verlag, 1993, 24.

19 Ibid., 24.

$20 \quad$ Ibid., 23. 
system of self-control has become completely externalized. All aggressive energies are unleashed and projected onto the enemy. This externalization has profound effects on the conduct and dispositions of a soldier, once he has returned to civilian life. All the aggressive energies of the $I d$, which, under normal circumstances, are kept under control by the Über-Ich, are now unleashed and allowed to proliferate. Because of the destruction of the psychological instruments for self-control - even for elementary instincts of self-preservation, and because of the unleashing of all the aggressive drives - the soldier will seek elements of protection and control outside of himself: in feelings of companionship, uniform behaviour, mass behaviour, sacrifice, external orders and unambiguous leaders, marching rhythms and military cadences such as the rhythm of soldiers' songs, and so on. These external elements are experienced as structuring elements for the soldiers, as protection against primal fears now that the psychological instincts that enable them to detect and avoid danger have been broken. This condition explains, according to Simmel, why the exsoldier will be drawn to mass rallies, party hierarchies, political demagogues, sloganeering, nationalist pathos, and so forth. Simmel connects this trait to the vulnerability of the masses for ideological extremes and political militias during the Weimar Republic.

Not surprisingly, the attitude of the war veteran towards his surroundings will be profoundly altered. As Freud already noticed with a certain puzzlement - which additionally made him rethink his older views on the pleasure principle in Jenseits des Lustprinzips (Beyond the Pleasure Principle) - war veterans seem to seek out certain situations compulsively. They display what is called a Wiederholungszwang, a compulsion to repeat. Simmel writes: "Das Ich des Kriegsneurotikers scheint die Angst zu suchen."21 Not only in his dreams, but also in his daily practices the veteran seems to seek up similar anxietyinducing situations. Simmel regards this as a mechanism to find a way to release an excess of energies but also as an attempt to learn to cope with this anxiety-inducing situation. However, the soldier has been drilled not to run away from objects or situations that cause fear, but to attack them.22

If war neurosis was indeed as widespread as Simmel or Döblin claimed, this illness had serious consequences for life in Berlin during the fragile and unstable post-war period. The state of war neurosis changes people's relation towards their life world profoundly. Their psychological coping mechanisms for dealing with traumatic experiences place a great urgency and tension on out fear." (Our translation). 
daily life. If these coping mechanisms should fail, the individual would be overwhelmed with extreme anxiety, possibly even threatening his or her frail psychological balance and coherence, leading to the complete breakdown and psychological disintegration of that individual. However, these same coping mechanisms turn the individual's life world into a constant experience of the warfront, whereby traumatic fears and anxieties are projected onto the outside world as elements to be eliminated.

When reading Berlin Alexanderplatz, the reader never gets any reference whatsoever to the previous life of Franz, nothing about his youth or his parents, other than flashbacks to his experiences as a soldier on the front and the violent murder of Ida. It is as if the past does not exist for Franz, except as fragments, sound bites and sudden associations from the war, which are inserted into the narrative in unexpected places, seemingly out of place with the rest of the narration. Moreover, Franz is a remarkably violent character, constantly seeking to numb his senses with copious amounts of alcohol. He also seems to get himself naïvely into dangerous, violent or criminal situations. Even when his criminal associates abuse his services and throw him out of a moving car after a robbery, causing him to lose an arm, he keeps on returning to the same criminals with even more disastrous consequences. For a figure who is so anxiety-stricken as Franz, barely being able to cope with the chaos of Berlin street life, even longing to be back in the relative calm and order of the prison where he spent five years, he seems to repetitively seek out the same forms of danger and perilous situations. Though he suffers from impotence at the beginning of the novel, he soon rapes the sister of his former wife. The fact that Franz is barely capable of keeping himself together, that he can only cope with the sensory chaos of the city with the greatest effort, that he never has any recollection of the past other than flashbacks of the front, that he compulsively seeks out danger and that he can only deal with problems in terms of violent, destructive reactions - all these circumstances suggest that Franz also suffers from war neurosis. He is drawn to party meetings although he doesn't seem to care whether they are on the far-left or the far-right and he often has associations of song fragments and children's rhymes, suggesting that he needs a simple cadence or rhythm to face the chaos around him. Children rhymes such as the following repeatedly recur in the novel: "Mit den Händchen klapp, klapp, klapp, met den Füßchen trapp, trapp, trapp."23 When his misfortunes finally become too much for him, he completely breaks down and is taken in

23 Alfred Döblin, Berlin Alexanderplatz, 119. "Our little hands go clap, clap, clap, our little feet go tap tap tap." Alfred Döblin, Berlin Alexanderplatz (trans), go. 
an almost lifeless stupor to the Buch psychiatric hospital, where Döblin had also worked.

Sometimes a passage with war associations is inserted into the novel in a seemingly random manner, completely out of place with what precedes or follows, such as the following:

Trompeten! Die Schlacht ist im Gang, die Regimenter marschieren, trara, trari, trara, die Artillerie und die Kavallerie, und die Kavallerie und die Infanterie, und die Infanterie und die Fliegerei, trari, trara, wir ziehen in feindliches Land hinein. Worauf Napoleon sagte: Vorwärts, vorwärts, ohne Unterlaß, oben ist trocken und unten naß. Aber wenn unten ist trocken geworden, erobern wir Mailand, und ihr kriegt ein Orden, trari, trari, trara, trari, wir ziehen an, wir sind bald da, o welche Lust, Soldat zu sein. $^{24}$

Even certain chapter titles are war or combat references, for example, "Verteidigungskrieg gegen die bürgerliche Gesellschaft", "Vorwärts, Schritt gefaßt, Trommelgerassel und Bataillone" or "Die beginnende Schlacht. Wir fahren in die Hölle mit Pauken und Trompeten." 25 Sometimes during a violent scene, such as when the arch-criminal Reinhold kills Franz's lover Mieze in a forest while a storm is coming, references to the war are inserted. The sound of the coming storm is associated with the sound of bombs: "Wumm, da kommt er wieder, Achtung, wumm, wumm, wumm, das sind Fliegerbomben, er will den Wald abreißen, er will den ganzen Wald erdrücken." ${ }^{26}$

Maybe the most striking usage of war flashbacks, songs or sounds, suggesting the effects of war neurosis, can be found in the passage where Franz goes to visit Reinhold, after Reinhold and his gang of criminals had already

24 Alfred Döblin, Berlin Alexanderplatz, 323. "Trumpets! The battle is on, the regiments are marching, tarara, tarari, tarara, Artillery and Cavalry, Cavalry and Infantry, the Infantry and the flying corps, tarari, tarara, we're pushing into the enemy's land. Whereupon Napoleon said: Forward, forward, without respite, go, it's dry above and wet below. But if it gets dry below we'll conquer Milan, and a medal will be given every man, tarari, tarara, tarari, tarara, we're going strong, we won't be long, oh, what joy to be a soldier boy!" Alfred Döblin, Berlin Alexanderplatz (trans.), 265.

25 Ibid., 264, 291, 396. "Defensive War against Bourgeois Society", "Forward, in Step, Roll of Drums and Battalions", "The Battle Begins. We ride to Hell with Trumpets and Drums." Alfred Döblin, Berlin Alexanderplatz (trans), 215, 239, 328.

26 Ibid., 354. "Woom, there it is back again, look out, boom, zoom, zoom, those are bombs from airplanes, it wants to tear the wood down, to crush the whole wood." Alfred Döblin, Berlin Alexanderplatz (trans), 292. 
thrown Franz out of a moving car. ${ }^{27}$ To the reader it is incomprehensible that Franz actually goes to the house of the ruthless devil-like character who nearly killed him. It is as if Franz is compulsively driven to get into the same kinds of danger, as if the hardships that befell him had not been awful enough and he wants even more. Not surprisingly, Franz is highly agitated when he approaches the house of Reinhold, not knowing what will happen. This agitation is intensified by the repeated insertion of war flashbacks into the narrative, which gives the impression that Franz is going into "combat mode." The danger he is facing triggers raw associations from the front. As Simmel had argued, the former soldier is trained in military combat drill, including marching rhythms and the orders from those in charge, to respond to threatening situations by means of attack. Franz's fear triggers a mixture of associations with the front and soldiers' songs or marching rhythms, as if he is marching towards the front for an offensive (the words "Offensive, Offensive" 28 are amongst the military associations inserted into the narrative).

This chapter - of which the title "Vorwärts, Schritt gefaßt, Trommelgerassel und Bataillone"29 already suggests a march towards combat - begins with the following lines: "Achtung, Mensch, wenn Granaten kommen, gibts Dreck, vorwärts, Beene Hoch, schlankweg durch, ick muß raus, vorwärts, mehr als die Knochen können mir nicht zerschlagen werden, dummdrummdumm, Schritt gefaßt, eins zwei, eins zwei, links rechts, links rechts, links rechts."30 The montage elements suggesting marching or anticipation of combat recur with repeated phrases and fragments throughout the chapter. Döblin added fragments from, or allusions to, existing soldiers' songs or children's rhymes into the montage constructions, as if Franz is trying to call up more persistence and courage. At the same time, these child-like rhymes suggest some kind of a psychological regression and a need for simple nursery rhymes, those used to soothe little babies:

27 For a more elaborate and detailed analysis of this and other passages in Berlin Alexanderplatz in terms of war neurosis, see Veronika Fuechtner, Berlin Psychoanalytic, 39-46.

28 Alfred Döblin, Berlin Alexanderplatz, 292. "Take the offensive, the offensive." Alfred Döblin, Berlin Alexanderplatz (trans), 240.

29 Ibid., 291."Forward, in Step, Roll of Drums and Battalions." Alfred Döblin, Berlin Alexanderplatz(trans), 239.

$30 \quad$ Ibid., 291. "Look out, old man, when the shells fall, there'll be dirt flying around, forward, step high, straight on through, I gotta get out, forward, all they can do is smash my bones, drumdrumm, druummmmmmmmmm. In step, one two, one two, left right, left right, left right." Alfred Döblin, Berlin Alexanderplatz (trans), 235. 
Da marschiert Franz Biberkopf durch die Straßen, mit festem Schritt, links rechts, links rechts, keine Müdigkeit vorschützen, keine Kneipe, nichts saufen, wir wollen sehen, eine Kugel kam geflogen, das wollen wir sehen, krieg ich sie, liege ich, links rechts, links rechts. Trommelgerassel und Bataillone. Endlich atmet er auf. Es geht durch Berlin. Wenn die Soldaten durch die Stadt marschieren, eiwarum, eidarum, ei bloß wegen dem Tschingdarada bumdara, ei bloß wegen dem Tschingdarada, dada. Die Häuser stehen still, der Wind weht wo er will. Eiwarum, eidarum, ei bloß wegen dem Tschingdaradada. ${ }^{31}$

This passage contains direct citations from the traditional soldiers' songs "Ich hatt' ein Kameraden" 32 or "Die Seeräuber."33 It contains an allusion to the Gospel of John ("der Wind weht wo er will" refers to John 3:8) and sound clips from marching drums or cymbals. Some of these phrases are repeated literally throughout the passage, which gives a sense of compulsion. Though the marching rhythm is supposed to help Franz gain composure, the montage of such diverse fragments, elements or allusions compressed into a few lines suggests wild, anxious associations, almost hallucinatory, or highly agitated sensory impressions that come crashing in frantically.

In another montage passage, Franz knocks on Reinhold's door and he is presented as a war cripple, though every reader knows that Franz came out of the war physically unscathed and that he lost his arm during his criminal activities after the war:

31 Ibid., 291-292. "Franz Biberkopf marches through the streets with a firm step, left right, left right, don't pretend to be tired, no saloons, no boozing now, we'll see about it, one ball wing'd by death came flying, that's what we'd like to see, if it's sent for me, I'm down, left right, left right. Roll of drums and battalions. At last he breathes easy. Marching through Berlin. When the soldiers go marching along through the town, oh why, just why, that's why, that's why, just because of tararara, tararara, just because of tararara taraboomdeeay. The houses stand still, the wind blows where it will. Oh why, just why, that's why, that's why, just because of tararara taraboomdeeay." Alfred Döblin, Berlin Alexanderplatz (trans), 239.

32 Written by Ludwig Uhland in 1809. The words of the second verse are: "Ein Kugel kam geflogen: Gilt's mir oder gilt es dir? Ihn hat es weggerissen. Er liegt vor meinen Füßen als wär's ein Stück von mir."

33 Written by Alexander Cosmar in 1839: "Wenn die Soldaten durch die Stadt marschieren, Öffnen die Mädchen die Fenster und die Türen. Ei warum? Ei darum! Ei warum? Ei darum! Ei bloß wegen dem Schingderassa, Bumderassa, Schingdara! Ei bloß wegen dem Schingderassa, Bumderassa, Schingdara!" 
Spring auf, marsch, marsch. Reinhold im Moment in die Tasche, Revolver. Eine Kugel kam geflogen, gilt er mir oder gilt sie dir. Sie hat ihn weggerissen, er liegt mir zu den Füßen, als wär's ein Stück von mir, als wär's ein Stuck von mir. Da steht er: Franz Biberkopf; Arm hat er ab, Kriegsinvalide, der Kerl ist besoffen, oder nicht. Macht er eine Bewegung, knall ich ihn nieder. ${ }^{34}$

By constructing a montage from war fragments, songs and sounds, the scene not only increases in tension - as if watching a film scene where the tension is raised by means of rapid jump-cuts - but the suggestion is also made that Franz approaches his surroundings, from the villain Reinhold to the city as such, in the way a person with war neurosis would act.

The passage where Franz has his final breakdown, leaving him speechless and almost lifeless, is often regarded as a turning point in the narrative. It seems as if Franz comes out of the Buch hospital as a man reborn, less naïve and destructive than before, more equipped to face the future. However, the last chapters, including the very last pages, are rife with phrases suggesting war or military marching, such as: "Die Trommel wirbelt hinter ihm. Marschieren. Marschieren. Wir ziehen in Krieg mit festem Schritt, es gehen mit uns hundert Spielleute mit, Morgenrot, Abendrot, leuchtest uns zum frühen Tod."35 This undercutting of the future-oriented narrative about Franz being able to make a new start with systematic references to war has led to the frequent observation that the ending of the novel is highly ambiguous. Though the narrative is filled with repeated warnings of caution (for example: "Wach sein, Augen auf, aufgepaßt, tausend gehören zusammen, wer nicht aufwacht, wird ausgelacht oder zur Strecke gebracht"), ${ }^{36}$ the final sentences sound once again war-like:

Und Schritt gefaßt und rechts und links und rechts und links, marschieren, marschieren, wir ziehen in den Krieg, es ziehen mit uns hundert

34 Alfred Döblin, Berlin Alexanderplatz, 292. "Attention! March, march! Reinhold's hand flies to the gun in his pocket. One ball wing'd by death came flying, is it sent for me or thee? Torn away from life and dying, As at my feet he's lying, He seems a part of me. He seems a part of me. There he stands, Franz Biberkopf, his arm's gone, a war-cripple, the fellow's drunk, or maybe not? If he makes a move, I'll bump him off." Alfred Döblin, Berlin Alexanderplzt (trans), 240 .

35 Ibid., 454. "The drums roll behind him. Marching, marching. We tramp to war with iron tread, a hundred minstrels march ahead, red of night and red of day, deathwards leads the way." Alfred Döblin, Berlin Alexanderplatz (trans), 378 .

36 Ibid., 454. "Keep awake, eyes front, attention, a thousand belong together, and he who won't watch out, is fit to flay and flout." Alfred Döblin, Berlin Alexanderplatz (trans), 378. 
Spielleute mit, sie trommeln und pfeifen, widebum, widebum, dem einen gehts grade, dem anderen gehts krumm, der eine bleibt stehen, der andere fällt um, der eine rennt weiter, der andere liegt stumm, widebum, widebum. $^{37}$

Is Franz facing a new and better future, or is he driven, along with many others, by old traumas straight towards fascism and a new war? Döblin could not refrain from grafting a strong element of caution and foreboding onto the final passages, avoiding a naïve belief in the future. Overcoming the effects of the previous war would require long and hard work.

The insertion of symptoms of war neurosis into the novel is not just an aspect of Berlin life like any other. It is not just part of Döblin's documental registration of the sights and sounds of Berlin. With the symptoms of war neurosis, a fundamental obstacle is introduced: a psychological affliction which jeopardizes the possibility of Bildung - of positive development, that is, whether it is personal or collective, thus rendering Franz Biberkopf's transformation and the hopeful ending of the novel highly ambiguous and, per definition, excluding the capacity to register the sensory experience of modern city life as Döblin envisioned it. The problem of war neurosis increases the stakes and intensity of what goes on in the novel by introducing into the montage passages an element that can exclude or transform other elements of the montage, adding an important tension to the montage and cautioning against facile, positive solutions.

It does not take long for money to become a problem in Berlin Alexanderplatz. For it is the story of an uncovered loan, a story of financial hubris, told to Franz Biberkopf by the Jews living in the Sophienstrasse. On the run from the noise of the Rosenthaler Strasse, the overwhelmed and scared ex-convict will soon be invigorated by the tale of Stefan Zannowich, an imposter who posed as an Albanian prince. Having received letters addressed to this prince of Albania, he is incited by his bad angel to take a loan on it - and so he does. As he is unable

37 Ibid., 454-455. And get in step, and right and left and right and left, marching: marching on, we tramp to war, a hundred minstrels march before, with fife and drum, drrum, brrum, for one the road goes straight, for another it goes to the side, one stands fast, another's killed, one rushes past, another's voice is stilled, drumm, brumm, drumm!" Alfred Döblin, Berlin Alexanderplatz (trans), 378. 
to pay the money back, however, Zannowich soon finds himself chucked out by the gallows. For Franz, the tale displays an apparent injustice: "Nun, waren doch noch andere gewesen sein wie der, wie der Stefan. Werden doch nicht alle Minister gewesen sein und Schinder und Bankiers." ${ }^{38}$ The story indeed has a tonic effect on Franz, who walks out into the streets with newly found courage.

The history of Stefan Zannowich displays a treacherous feature in the modern understanding of finances: things are valuable only because society believes them to be, their appeal does not recur to some intrinsic nucleus of value. This being especially true of paper money, Zannowich's story would have had a contemporary touch in 1920s Berlin, as it lays bare the mechanism behind what Adam Ferguson has dubbed "this most tragic and upsetting of human experiences": German hyperinflation. ${ }^{39}$ As Ferguson puts it,

$[\mathrm{T}]$ he process of collapse of the recognized, traditional, trusted medium of exchange, the currency by which all values are measured, by which social status is guaranteed, upon which security depends, and in which the fruits of labour are stored, unleashes such greed, violence, unhappiness, and hatred, largely bred from fear, as no society can survive uncrippled and unchanged. ${ }^{40}$

The specific causes of this hyperinflation still under debate between different economists, one can nevertheless sum up the circumstances under which the financial extravaganza of the endlessly depreciating Reichsmark took place: political radicalization from both the left and the right, social upheaval, occupied Rhine ports, miners' strikes, a weak central government unable either to efficiently levy taxes nor counter demands from unions or industrialists, and finally the extreme burden of war reparations imposed on the fragile Weimar Republic. All of this culminated by the end of 1923 in completely unfathomable figures, as one French franc could buy its bearer up to a trillion German marks. ${ }^{41}$

In his posthumous autobiography Die Welt von Gestern (The World of Yesterday), Stefan Zweig delivers one of many literary testimonies of these events.

38 Alfred Döblin, Berlin Alexanderplatz. Die Geschichte vom Franz Biberkopf. München, dtv, 2007, 29. "Well, there were probably others like him, like Stefan. Most likely they weren't all ministers and knackers and bankers." Alfred Döblin, Berlin Alexanderplatz (trans), 16.

39 Adam Fergusson: When Money Dies: The Nightmare of Deficit Spending, Devaluation, and Hyperinflation in Weimar Germany. London, Kimber, 1975, 9.

$40 \quad$ Ibid., 15.

41 Ibid., $14 f f$. 
Although having already experienced substantial inflation in his native Austria after the Great War, he can only conclude: "Was wir in Österreich gesehen, erwies sich nur als mildes und schüchternes Vorspiel dieses Hexensabbats, denn die Deutschen brachten ihre ganze Vehemenz und Systematik in die Perversion." ${ }^{\text {22 }}$ Berlin, in Zweig's testimony, turned into a twentieth-century Babel:

Eine Art Irrsinn ergriff im Sturz aller Werte gerade die bürgerlichen, in ihrer Ordnung bisher unerschütterlichen Kreise. Die jungen Mädchen rühmten sich stolz, pervers zu sein; mit sechzehn noch der Jungfräulichkeit verdächtig zu sein, hätte damals in jeder Berliner Schule als Schmach gegolten, jede wollte ihre Abenteuer berichten können und je exotischer, desto besser. ${ }^{43}$

Money, once a dull medium of measurement, only interesting in the eyes of the beholding bookkeeper or businessman, had become - in the words of Elias Canetti - "[e]in Dämon mit einer Riesenpeitsche, so schlug es auf alles ein und erreichte die Menschen bis in ihre geheimsten Mauselöcher."44 As the potency of money to signify reliably the pecuniary order of things declined rapidly and melted away altogether eventually, the social stratifications and cultural boundaries delimited by it quickly vanished into thin air. If money, despite the abundance of zeroes, could no longer signify anything, then what could traditions, appearances, manners, or even language itself legitimately aspire to? Such inflation was not a mere loss of reference on the monetary front, but a fundamental problem of referentiality that permeated across Weimar society in its entirety.

42 Stefan Zweig, Die Welt von Gestern. Erinnerungen eines Europäers. Frankfurt am Main, Fischer Taschenbuch Verlag, 2007, 357. "What we had seen in Austria was only a mild and gentle prelude to this witches'sabbath, for the Germans now turned their methodical methods to the cause of perversions." Stefan Zweig, The World of Yesterday, London, Pushkin Press, 2009, 338.

43 Stefan Zweig, Die Welt von Gestern, 357. "Amidst the headlong fall of all values, a kind of madness took hold of the bourgeois circles that had so far resisted any change to their well-ordered society. Young girls boasted proudly of perversities; to be suspected on still being a virgin at the age of sixteen would have been thought a disgrace in any Berlin school. Every girl wanted to be able to boast of her adventures, and the more exotic they were the better." Stefan Zweig, The World of Yesterday, 338.

44 Elias Canetti, Die Fackel im Ohr. Lebensgeschichte 1921-1931, München, Wien, Carl Hanser Verlag, 1980, 62. "a demon with a gigantic whip, lashing at everything and reaching people down to their most private nooks and crannies." Elias Canetti, The Memoirs of Elias Canet$t i$, New York, Farrar, Straus and Giroux, 1999, 329.

For use by the Author only | (c 2019 Koninklijke Brill NV 
Small wonder, then, that in the rapid, documentary sequences of images from Berlin life, and among the various stupefying encounters of Biberkopf that populate Berlin Alexanderplatz, the traumatic experience of inflation, depreciating values and diminishing cultural referentiality are poetically documented. A trauma, in the strict sense, is exactly what appears to have overcome the small, fat asthmatic man that Franz encounters in a staircase. Out of breath from climbing down the stairs, he explains to Franz the nature of his business:

Ich habe meine kleine Rente. Ich wollte nu mal, sehen Sie, ein freier Mann sein, arbeiten, mein Geld verdienen. Na, seit drei Jahren hab ich meine kleine Pension, solange war ich bei der Post, und nu loof ick und loof ick. Also: ich lese in der Zeitung, und dann geh ich hin und seh mir an, was die Leute anzeigen. [...] Na, dann geh ich rauf und seh mir an, und dann koof ich ooch. ${ }^{45}$

"Und dann verkoofen Sie weiter, versteh", ${ }^{46}$ Franz adds - mistakenly. For the poor man has made a strange, compulsive habit out of running up and down stairs, making deals over valuables other people are trying to sell, only to leave a note at the door afterwards, stating that he is forced to renounce the previously made engagement. "Und dann geh ich runter, möchte ja ooch so gerne alles koofen, aber unten, da krieg ich dann die dikken Sorgen: keen Geld und keen Geld." 47

Franz's astonishment is legitimate: “[W]ofür denn aber?"48 The asthmatic pensioner, former mailman, belongs to a class of citizens that would have suffered most dearly under the effects of inflation: those on fixed incomes, who only saw their wages adjusted to inflation with great delays - if ever. He appears to neurotically re-enact, day by day, an activity that was very customary during this hyperinflation. Knowing that the money they held in their pockets would soon lose all value, people would regularly besiege the shops to embark

45 Alfred Döblin, Berlin Alexanderplatz, 202. "I got a little pension. Y'see I wanted to be a free man; work and earn my money. Well, I've had my pension for three years now, was in the postal service before, and now I do nothing but hoof it all the time. Y'see it's like this: I read the paper and then I go there and take a look at what people advertise. [...] Well, then I go up and look at the stuff, and sometimes I buy something." Alfred Döblin, Berlin Alexanderplatz (trans), 161-162.

46 "And then you sell it again, I getcha." Alfred Döblin, Berlin Alexanderplatz (trans), 162.

47 Ibid., 203. "And then I go downstairs, I'd really like to buy everything, but downstairs I get to worrying a lot: no money and still no money." Alfred Döblin, Berlin Alexanderplatz (trans), 162 .

Ibid., 203. "[B]ut what for?" Alfred Döblin, Berlin Alexanderplatz (trans), 163. 
on a purchasing mania, desperately trying to exchange their quickly depreciating money for something of value.

In the chapter "Schwunghafter Mädchenhandel", ${ }^{49}$ Biberkopf himself refers to another fashionable habit of hyperinflation. When his dubious acquaintance Reinhold tries to rid himself regularly of yet another of his many sweethearts by pairing her off with wide-eyed Franz, the latter calls this "Kettenhandel, was, wie in der Inflation?"50 The so-called "Kettenhandel" consisted of deliberately lengthening supply routes of commodities by inserting an unnecessary amount of mediators - who could then all have a slice of the seller's margin whilst the commodities' continued to increase in price during the lengthy process of actually delivering them to consumers. Having helped Reinhold to get rid of his first girl Fränze, he is quickly asked to take over the next one, Cilly. Reinhold tries to persuade him into the deal by arguing that Fränze appears to only wear summer clothes. With winter coming, she will soon require a new outfit, so Franz ought better to dispose of her, before she starts to cost him dearly. Reinhold himself does seem to recognize that his understanding of women has a pathological trait, as he explains to Franz:

Weißt doch, daß mir die Weiber so rasch über werden. Siehst es ja, Mensch. Nach vier Wochen, dann ist aus. Warum, weeß ich nicht. Mag sie nicht mehr. Und vorher bin ich verrückt nach einer, müßtest mich mal sehen, total verrückt, direkt zum Einsperren in die Gummizelle, so verrückt. Und nachher: nischt - raus muß sie, kann sie nicht sehen, könnte noch Geld hinterherwerfen, wenn ich sie bloß nicht sehe. ${ }^{51}$

This situation is, of course, not the only occurrence of women circulating in Franz's Berlin as if they were commodities. Prostitution is ubiquitous, and Franz himself will play the dubious role of pimp after one of his many falls into sin.

Money and prostitution, the German sociologist Georg Simmel argued in his Philosophie des Geldes (Philosophy of Money), which went through two

49 "Spirited White Slavery" Alfred Döblin, Berlin Alexanderplatz (trans), 140.

50 Ibid., 180. "a kind of chain business, like they did during the inflation." Alfred Döblin, Berlin Alexanderplatz (trans), 142.

$5^{1} \quad$ Ibid., 183-184. "Y'know I get tired of the dames very quick. You can see that, can't you? Four weeks, and that's all. I don't know why. Don't like'em any more. And up to that time I was crazy about 'em, you ought to see me, completely gone, enough to put in a padded cell, that's how crazy I get. And afterwards - nothin', out they go, ca't see'em." Alfred Döblin, Berlin Alexanderplatz (trans), 145 . 
editions in the early twentieth century, are intrinsically interlinked. Simmel's views on money specifically revolve around the role it plays in what he calls the objective culture of modernity. This culture is characterized by a scientific, sober appreciation of the world, by automated, almost mechanized proceedings, in which mostly anonymous citizens act in a very distant manner towards one another. Another typical trait of this culture is the relativity of social and monetary values, which are constantly weighed against each other, rather than being derived from an absolute significance. The modern understanding of money, Simmel argues, is on all levels a prime example of what this objective culture implies, and this condition again proves to be the case specifically when considering its power to purchase even the most intimate form of human interaction. Money, as a medium, is not capable of expressing any time-enduring relationship between people, but all the more the interaction that characterizes prostitution: "Der momentan aufgegipfelten und ebenso momentan verlöschenden Begierde, der die Prostitution dient, ist allein das Geldäquivalent angemessen, das zu nichts verbindet [...]."52 Money's indifference, its unfaithfulness and heartless objectivity render it analogous to prostitution: " $[\mathrm{D}]$ ie fürchterliche, in der Prostitution liegende Entwürdigung [findet] in ihrem Geldäquivalent den schärfsten Ausdruck [...]."53

Franz Biberkopf's Berlin is, then, by all means a modern one, but Franz's comment on Reinhold's suggestion - "Wie in der Inflation, was? - does disclose a significant difference. For if Reinhold's sweethearts are subject to inflation, they resemble more a currency than a commodity, circulating ever more rapidly to counter the loss of purchasing power, that is, the loss of significance. Franz's rather cynical remark illustrates again how in a modern, anonymous and objective culture the mechanics of severe depreciation in the monetary sphere are mirrored within the most intimate interactions in society. ${ }^{54}$ As the

52 Georg Simmel, Philosophie des Geldes. Köln, Anaconda Verlag, 20o9, 594. "Only money, which does not imply any commitment, and which in principle is always at hand and welcomed, is the appropriate equivalent to the fleetingly intensified and just as fleetingly extinguished sexual appetite that is served by prostitution." Georg Simmel, Philosophy of Money. Translated by Tom Bottomore and David Frisby from a first draft by Kaethe Mengelberg. New York, Routledge Classics, 1990, 407.

53 Ibid., 595. "[T] he terrible degradation that is inherent in prostitution is most clearly expressed by its money equivalent." Georg Simmel, Philosophy of Money, 408.

54 For an in-depth inquiry into social, and specifically gender-related issues caused by this inflation, see Nicole Shea, The Politics of Prostitution in Berlin Alexanderplatz, Bern, Peter Lang, 2007, 35f. Inflation caused many young working-class women to lose the little savings they had, which ought to have served as dowry. Although this loss meant cultural liberation, it did severely confuse their sexual identity. 
example of Franz's asthmatic acquaintance has shown: it is best to get rid of money during an inflationary crisis, before raging depreciation causes one to lose rather than save money. What appears to Franz to be a commercial habit, once necessitated by inflation, evokes the dire moral consequences of that hyperinflation described by Zweig and Canetti: if modernity is characterized by money being the measure of all things, then the referential turmoil cannot be limited to monetary values, but will necessarily corrupt social and moral values.

One of the most emblematic montage scenes in Berlin Alexanderplatz depicts the slaughterhouses at the Landsberger Allee. ${ }^{55}$ As with the long sequence of scenes that starts at the Rosenthaler Platz, the novel displays - without further commenting upon them - technical, almost encyclopaedic details, that appear to have been copied from existing documents:

Er bedeckt eine Fläche von 47,88 ha, gleich 187,50 Morgen, ohne die Bauten hinter der Landsberger Allee hat das 27093492 Mark verschluckt, woran der Viehhof mit 7 Millionen 682844 Mark, der Schlachthof mit 19 Millionen 410648 Mark beteiligt ist. ${ }^{56}$

The sequence of scenes more or less follows the entire production process: from the negotiating cattle handlers outside, through the process of killing the animals, to images of a well-lit butcher's shop, and instructions on how to prepare a meal of Spitzbeine. Yet as with the depicted murder of Franz's lover Ida, radically different types of language are paratactically assembled. As in previous scenes, in which monetary issues were intertwined with religious and moral questions - Zannowich's bad angel, or the trade in women - the slaughterhouse scenes are marked by economic facts alternating with bucolic-like scenes - "Fröhliche Weiden, dumpfer, warmer Stall" ${ }^{57}$ - and an emphatically mystical language of sacrifice. It is a language which in its turn has overt similarities with the one used to describe the murder on Mietze, and Biberkopf's

55 A cultural-historical inquiry into the slaughterhouse topos is given in Armin Leiding, Hure Babylon: Großstadtsymphonie oder Angriff auf die Landschaft? Alfred Döblins Roman Berlin Alexanderplatz und die Großstadt Berlin: eine Annäherung aus kulturgeschichtlicher Perspektive, Würzburg, Königshausen \& Neumann, 2010, 332ff.

56 Alfred Döblin, Berlin Alexanderplatz, 136. They cover an expanse of 47.88 hectares, equal to 118.31 acres. Not counting the structures behind Lands-berger Allee, 27083492 marks were sunk into this construction, of which sum the cattle-yars cost 7682844 marks, and the slaughter-house 19410648 marks." Alfred Döblin, Berlin Alexanderplatz (trans), 103.

Alfred Döblin, Berlin Alexanderplatz, 142. Happy pastures, damp warm stable. Alfred Döblin, Berlin Alexanderplatz (trans), 109. 
moral, physical and ultimately psychic downfall later in the novel. A case in point is the phrasing of a big, white bull's arteries being cut open:

Jetzt wird das Messer angesetzt werden, und das Blut wird herausstürzen, ich kann es mir schon denken, armdick im Strahl, schwarzes, schönes, jubelndes Blut. Dann wird der ganze lustige Festjubel das Haus verlassen, die Gäste tanzen hinaus, ein Tumult, und weg die fröhlichen Weiden, der warme Stall, das duftende Futter, alles weg, fortgeblasen, ein leeres Loch, Finsternis, jetzt kommt ein neues Weltbild. Oha, es ist plötzlich ein Herr erschienen, der das Haus gekauft hat, Straßendurchbruch, bessere Konjunktur, er wird abreißen. Man bringt die große Schale, schiebt sie ran, das mächtige Tier wirft die Hinterbeine hoch. ${ }^{58}$

The fragments from the commercial practices behind the slaughterhouse, including investment and market information, are juxtaposed with what appears to be a scene of sacrifice, conjuring up a "new world", which is then again followed by events from the real estate market.

Does this suggest that these sacral rituals and commercial events are intertwined? It is a remarkable fact that this idea on the common roots of sacrifice and modern monetary and market practices was launched only a few years earlier, in 1924, by the classics scholar Bernhard Laum, in his work Heiliges Geld: Eine historische Untersuchung über den sakralen Ursprung des Geldes. ${ }^{59}$ As Laum explains in the preface, the book was written in the summer of 1923, at the moment when hyperinflation escalated into its most extreme phase. The book explains Laum's hypothesis, namely that modern charter money was invented in ancient Greece, where human sacrifices were first replaced by animals - preferably big, white bulls -, who in their turn were eventually replaced by coins. In the process, the temples themselves became centres of trade and commerce, where exchange was effectuated with the novel currency.

$5^{8}$ Alfred Döblin, Berlin Alexanderplatz, 142. "Now he applies the knife, the blood will gush out, I can see it now, in a stream as thick as your arm, black, beautiful, jubilating blood. Then the whole merry party will leave the house, the guests will dance out into the open, a tumult, and gone are the happy pastures, the warm stable, the fragrant fodder, everything gone, blown away, an empty hole, darkness, a new cosmos emerges! Haha! Suddenly we see a gentleman who has bought the house, new streets being laid out, better business conditions, going to tear down everything. They bring the big basin, shove it up to him, the huge animal throws its hind legs in the air." Alfred Döblin, Berlin Alexanderplatz (trans), 108 .

59 The title translates freely as "Holy Money: A Historical Inquiry into the Sacral Origins of Money." 
In her book Der Preis des Geldes: eine Kulturgeschichte, the cultural historicist Christina von Braun has argued that the fact that Laum pushed forward this thesis at the height of this German hyperinflation is not a coincidence. The idea that money requires physical, bodily sacrifices in order to express a notion of value successfully must have been obvious for those who had to endure the consequences of its most severe depreciation, as Von Braun puts it. ${ }^{60}$ In Döblin's Berlin Alexanderplatz, the paratactic montage of images and documents reveals the sacral, religious creation behind the commercial world of shiny shops.

Yet here, too, the montage is more than a mere formal addendum. As referred to earlier in this paper, the montage technique does not leave the novel's narrative unaltered. For the rhetoric of sacrifice extends undoubtedly into the story of Franz Biberkopf's becoming, specifically his moral downfall, resulting in him being destroyed and newborn. "Hier saust der Hammer gegen Franz Biberkopf", the title of the seventh book, announcing his downfall, is clearly a reminiscence of the slaughtering scene, as are the scattered quotes from the depiction of Reinhold's murdering of Mieze "When man ein Kälbchen schlachten will, bindet man ihm einen Strick um den Hals, geht mit ihm an die Bank. Dann hebt man das Kälbchen hoch, legt es auf die Bank und bindet es fest." ${ }^{11}$ Biberkopf, it appears, has to pay the price for his hubris, his excessive desires in life, his surrender to the world of easy money and thus his moral decline and eventual breakdown.

His story began with another story - that of Stefan Zannowich, whose bad angel lured him into an act of forgery - and thus with a reflection on the epistemological status of modern money. Money, in the aftermath of such chaotic inflation, continues to wreak havoc among the Berliners of the 1920s: it is the medium of trauma, which one desires, but from which one might just as well flee in a compulsive purchasing mania. The pattern of its failing referential capacity is transposed onto human relations, making them numerous yet meaningless and ephemeral, demanding replacement and revival ever more rapidly. And all those who, like Franz Biberkopf, make this all-too-human error "vom Leben mehr zu verlangen als das Butterbrot" 62 will find that money, this shifty medium and measure of wealth and desire, has a price. It does not, as inflation

6o Christina von Braun, Der Preis des Geldes: eine Kulturgeschichte. Berlin, Aufbau Verlag, 48.

61 Alfred Döblin, Berlin Alexanderplatz, 351. "When a little calf is to be slaughtered, they tie a rope around its neck and lead it to the bench. Then they lift the little calf, put it on the bench, and tie it firmly." Alfred Döblin, Berlin Alexanderplatz (trans), 289.

62 Ibid., 12. "ask more from life than a piece of bread and butter." Alfred Döblin, Berlin Alexanderplatz (trans), 2. 
has forever made clear, recur upon an ontological essence of value, but - Bernhard Laum would agree - on a bloody act of sacrifice.

Life in Berlin had been traumatizing in the years leading up to the publication of Döblin's novel. The First World War sent home traumatized soldiers, for whom the war might never end, and the inflation that ensued in the years after the defeat shook the fragile Weimar Republic. The novel does not so much owe its epic nature, its vast scope covering the multitude of urban, social and historical events, to the story of Franz Biberkopf, to the narrative about his history and becoming; rather, as this article demonstrates, it is the process of montage, the artful interlacing of documents from Berlin life in the twenties, that makes it the novel it is.

\section{Bibliography}

Benjamin, Walter, Gesammelte Schriften, Band 3, ed Hella Tiedemann-Bartels, Frankfurt am Main, Suhrkamp, 1991.

Benjamin, Walter, Selected Writings, Volume 2 eds. Michael W. Jennings, Howard Eiland, Gary Smith. Trans. Rodney Livingstone et al. Cambridge and London, The Belknap Press of Harvard University Press, 1999.

Canetti, Elias, Die Fackel im Ohr. Lebensgeschichte 1921-1931. München/Wien, Carl Hanser Verlag, 1980.

Canetti, Elias, The Memoirs of Elias Canetti, Trans. Joachim Neugroschel. New York, Farrar, Straus and Giroux, 1999.

Döblin, Alfred, Aufsätze zur Literatur, ed Walter Muschg, Olten und Freiburg im Breisgau, Walter Verlag, 1963.

Döblin, Alfred, Berlin Alexanderplatz, Trans. Eugene Jolas. London and New York, Continuum, 2004.

Döblin, Alfred, Berlin Alexanderplatz, München, Deutcher Taschenburg Verlag, 2007.

Dollenmayer, David B. “An Urban Montage and Its Significance in Döblin's Berlin Alexanderplatz", The German Quarterly, Vol. 53/3 (May, 1980), 317-336.

Ferguson, Adam, When Money Dies. The Nightmare of the Weimar Collapse. London, William Kimber, 1975.

Fore, Devin, “Döblin's Epic: Sense, Document, and the Verbal World Picture”, New German Critique, No.99 (Fall, 2006), 171-207.

Fuechtner, Veronika, Berlin Psychoanalytic, Psychoanalysis and Culture in Weimar Republic Germany and Beyond, Berkeley, Los Angeles, London, University of California Press, 2011.

Horn, Eva, "Literary Research: Narration and the Epistemology of the Human Sciences in Alfred Döblin", MLN, Vol.18/3 (April, 2003), 719-739.

\section{For use by the Author only | ( 2019 Koninklijke Brill NV}


Laum, Bernhard, Heiliges Geld: eine historische Untersuchung über den sakralen Ursprung des Geldes. Tübingen, Mohr Siebeck, 1924.

Leiding, Armin, Hure Babylon: Großstadtsymphonie oder Angriff auf die Landschaft? Alfred Döblins Roman Berlin Alexanderplatz und die Großstadt Berlin: eine Annäherung aus kulturgeschichtlicher Perspektive, Würzburg, Königshausen \& Neumann, 2010.

Schäffner, Wolfgang, Die Ordnung des Wahns, Zur Poetologie psychiatrischen Wissen bei Alfred Döblin, München, Wilhemn Fink Verlag, 1995.

Shea, Nicole, The Politics of Prostitution in Berlin Alexanderplatz, Bern, Peter Lang, 2007. Simmel, Ernst, Psychoanalyse und ihre Anwendungen. Ausgewählte Schriften, eds Ludger M. Hermanns, Ulrich Schultz-Venrath, Frankfurt am Main, Fischer Verlag, 1993.

Simmel, Georg, Philosophy of Money. Trans. Tom Bottomore and David Frisby from a first draft by Kaethe Mengelberg. New York, Routledge Classics, 199 o.

Simmel, Georg, Philosophie des Geldes [1907]. Köln, Anaconda Verlag, 2009.

von Braun, Christina, Der Preis des Geldes. Eine Kulturgeschichte. Berlin, Aufbau Verlag, 2012.

Zweig, Stefan, Die Welt von Gestern. Erinnerungen eines Europäers. Frankfurt am Main, Fischer Taschenbuch Verlag, 2007.

Zweig, Stefan, The World of Yesterday, Trans. Anthea Bell. London, Pushkin Press, 2009.

\section{For use by the Author only | ( 2019 Koninklijke Brill NV}

